\title{
Ozone in polycyclic aromatic hydrocarbon degradation
}

\author{
Lilian dos Santos SILVA ${ }^{1 *}$, Osvaldo RESENDE ${ }^{1}$, Jaqueline Ferreira Vieira BESSA ${ }^{1}$, \\ Iaquine Maria Castilho BEZERRA ${ }^{1}$, Silvia Amélia Verdiani TFOUNI ${ }^{2}$
}

\begin{abstract}
Among energy sources from food, corn is a cereal with significant nutritional characteristics. However, during preprocessing, corn is subject to contamination by polycyclic aromatic hydrocarbons, which are considered carcinogenic, and gas ozone can be used as an alternative for decontamination. This study aims to evaluate the effect of ozonation on the quality of corn grains at different exposure times. Evaluations were performed to assess moisture content, electrical conductivity, germination, germination speed index, colour (brightness parameter, direction red to green, direction yellow to blue, hue angle indicates the colour tone and chroma), and chemical composition, and chromatographic analysis was performed to quantify the polycyclic aromatic hydrocarbons. The ozonation times influence on the quality of the maize grains was lipids, ash and germination percentage and did not promote the degradation of all the polycyclic aromatic hydrocarbons detected in the product.
\end{abstract}

Keywords: contamination; corn; drying.

Practical Application: Analyze the degradation of polycyclic aromatic hydrocarbons in maize after ozonation.

\section{Introduction}

To meet the needs for both food and feed, maize is a cereal expressly produced for its nutritional and energy characteristics and has become one of the most cultivated grains in the world (Camilo et al., 2015; Pinto et al., 2010; Rocha-Olivieri et al., 2012).

Polycyclic aromatic hydrocarbons (PAHs) are organic compounds formed by the incomplete combustion of organic materials. PAHs are composed of two or more benzene rings, are considered environmental contaminants, and may be present in soil, water and air. This environmental contamination may lead to the contamination of food by PAHs still in the fields (Rojo Camargo \& Toledo, 2003).

PAHs can form in foods during production processes, such as smoking, drying and roasting, and may be present in a variety of products, such as oils, fats, vegetables, fruit and coffee (Camargo et al., 2007; Drabova et al., 2013; Tfouni et al., 2014; Wang et al., 2011; Xu et al., 2013).

JECFA (Joint Committee FAO / WHO Expert Committee on Food Additives) considers the following 13 PAHs to be carcinogenic and genotoxic: benz [a] anthracene $(\mathrm{BaA})$, chrysene (Chr), 5-methylchrysene (5MChr), benzo [j] fluoranthene (BJF) benzo [b] fluoranthene (BbF), benzo [k] fluoranthene (BKF), benzo [a] pyrene $(\mathrm{BaP})$, dibenzo $[\mathrm{a}, \mathrm{l}]$ pyrene (DalP) dibenz $[\mathrm{a}, \mathrm{h}]$ anthracene (Daha), indeno [1,2,3-cd] pyrene (ICPD) dibenzo [a, e] pyrene (DAEP), dibenzo [a, i] pyrene (DAIP) and dibenzo $[\mathrm{a}, \mathrm{h}]$ pyrene (DAHP) (World Health Organization, 2005). Benzo(a) pyrene is classified in group $1 \mathrm{~A}$ (carcinogenic to humans) by the IARC (International Agency for Research on Cancer) (International Agency for Research on Cancer, 2010).
The European Union sets ceilings for four PAHs in some food categories. The limits range from $1.0 \mu \mathrm{g} \mathrm{kg}^{-1}$ to $6.0 \mu \mathrm{g} \mathrm{kg}^{-1}$ for BaP and $1.0 \mu \mathrm{g} \mathrm{kg}^{-1}$ to $30.0 \mu \mathrm{g} \mathrm{kg}^{-1}$ for the sum of four PAHs (pAH4: BaA Chr, BbF and BKF) (The Commission of the European Communities, 2011). In Brazil, the legislation only sets limits on $\mathrm{BaP}$ in the following categories: drinking water, smoke aroma and olive pomace oil (Brasil, 2003, 2004, 2007).

PAHs are compounds that may contaminate stored grains as they are formed in the furnace during the drying process by the use of the direct combustion of firewood as fuel and high combustion temperatures (Klautau, 2008; Rozentãle et al., 2015).

To improve food quality, ozone gas, a powerful oxidizing agent, is used in post-harvest operations for decontaminating microorganisms such as bacteria and fungi, although its effectiveness also includes protozoa, viruses and fungus spores, in addition to insecticides and food quality control (Bermúdez-Aguirre \& Barbosa-Cánovas, 2013; Cantalejo et al., 2016; Ong et al., 2013; White et al., 2010).

Ozone has many advantages including maintaining the physiological characteristics of the food, its speed of degradation, and producing oxygen $\left(\mathrm{O}_{2}\right)$ as a byproduct (Laureano et al., 2016).

Given the above, this study aims to investigate the effect of ozone gas at different exposure times on polycyclic aromatic hydrocarbon degradation (PAHs) and the quality of maize grain, evaluate maize conditions before and after the procedures adopted for evaluation.

${ }^{1}$ Laboratório de Pós-colheita de Produtos Vegetais, Instituto Federal de Educação, Ciência e Tecnologia Goiano - IF Goiano, Campus Rio Verde, Rio Verde, GO, Brasil

${ }^{2}$ Centro de Ciência e Qualidade de Alimentos, Instituto de Tecnologia de Alimentos - ITAL, Campinas, SP, Brasil

*Corresponding author: lilianquimica2@gmail.com 


\section{Materials and methods}

Maize grains (Zea mays L.) produced in the Rio Verde region - GO, provided by the company CARAMURU S/A with a moisture content of $16.38 \%$ (b.u.) were used for the experiment. The samples were analysed in the Vegetable Products Post-harvest Laboratory of the Federal Institute of Education, Science and Technology, Goiano (IF Goiano - Campus Rio Verde).

The grains were passed through a drying process by natural convection using a direct fire furnace to produce PAH contamination. The grains remained for approximately 30 minutes at the dryer air temperature of $113{ }^{\circ} \mathrm{C}$ and $55^{\circ} \mathrm{C}$ in the grain mass. Then, they were used as fuel with eucalyptus chips with a particle size of 3 to $5 \mathrm{~cm}$, and the moisture content was reduced to $11.5 \%$ (b.u.).

Analyses were performed to determine the levels of 13 PAHs (BaA, Chr, 5MChr, BJF, BbF, BKF, BaP, DalP, Daha, ICDP, DAEP, EOAD and DAHP) after ozonation using high efficiency liquid chromatography with fluorescence detection. The sample preparation was based on Speer et al. (1990). For this analysis, a Shimadzu gas chromatograph was used with a quaternary pump, auto sampler and column, which was oven stable at $30^{\circ} \mathrm{C}$.

Column chromatography (Vydac 201 TP 54 C18, 250 x 4.6 mm) was used for separation with particles of $5 \mu \mathrm{m}$, at a flow of $1 \mathrm{~mL}$ $\mathrm{min}^{-1}$ and with a gradient of acetonitrile water. The detection was made by a wavelength program. The method was a detection limit of $0.12 \mu \mathrm{g} \mathrm{kg}^{-1}$ for all PAHs except ICPD and BJF $\left(1.2 \mu \mathrm{g} \mathrm{kg}^{-1}\right)$.

After confirming the presence of PAHs, the samples were subjected to fumigation with ozone gas. The ozone generating equipment, supplied by VEC-XT, a partner company of Interozone of Brazil, LTDA, was used to obtain the ozone $\left(\mathrm{O}_{3}\right)$ by dielectric barrier discharge (DBD). The exposure of the maize grain to ozone was performed according to the methodology described by Pereira et al. (2008).

The dried samples were ozonized in triplicate by natural convection in a direct fire furnace at the following different times: 0 (no ozonation), $4,8,12,16,20$ and $24 \mathrm{~h}$ on a $0.40 \times 0.45 \times 0.55 \mathrm{~m}$ polyvinyl chloride (PVC) airtight container coupled to the ozone generator. The environmental average temperature was $30 \pm 2{ }^{\circ} \mathrm{C}$, and the relative humidity was $53 \pm 6 \%$.

At the bottom and the top right side of one of the compartments, the inlet and outlet gas was installed. At a height of $10 \mathrm{~cm}$ from the bottom of the container, a PVC grid pattern was included to support the grain and to form a plenum chamber for the better distribution of gas. The exhaust side is connected to another container of similar dimensions to release residual ozone before discharge into the atmosphere to ensure the neutrality of the "wall effect".

After ozonation, the samples were further analysed to quantify the PAHs.

The ozone concentration was determined by the iodometric method described by Clesceri et al. (2000).

From the values of constants B and C, according Venegas et al. (1998), it is possible to obtain the saturation time for each combination and gas flow.

The concentration of ozone was $1.74 \mathrm{mg} \mathrm{L}^{-1}$, and the saturation time was $112 \mathrm{~min}$.

The samples were evaluated in triplicate for the following: moisture content (MC), according to the American Society of Agricultural Engineers (2003); germination percentage (\% G), according to the method in Maguire (1962); electrical conductivity (EC), according to Vieira \& Krzyzanowski (1999); classification of grains, according to Brasil (2010); colour analysis taking (Color Flex EZ, Hunter Lab Reston, Canadá) into consideration the brightness parameter $\left(\mathrm{L}^{*}\right)$, direction red to green $\left(\mathrm{a}^{*}\right)$ and direction yellow to blue $\left(b^{*}\right)$; and hue angle $(h)$ indicates the colour tone and chroma $\left(\mathrm{C}^{\star}\right)$ indicates the colour intensity, as determined by the following Equations 1 and 2, according Alencar et al. (2010):

$$
\begin{aligned}
& H(h)=\operatorname{tg}-1 \frac{b^{*}}{a^{*}} \\
& \text { Croma } C=\sqrt{\left(a^{*}\right)^{2}+\left(b^{*}\right)^{2}}
\end{aligned}
$$

The centesimal composition evaluated the proteins, lipids, crude fibre, ash, moisture content and carbohydrates according to Silva \& Queiroz (2006).

The experiment was conducted using a randomized design (RD), with seven ozonation times $(0,4,8,12,16,20$ and $24 \mathrm{~h})$. The data were analysed by analysis of variance with a $5 \%$ significance level. For the qualitative factor, the means were analysed using the Scott-Knott test to evaluate the effect of the exposure times, adopting the 5\% significance level.

\section{Results and discussion}

Table 1 presents the summary of the analysis of variance with the mean square values of the moisture content (MA), electrical conductivity $(\mathrm{EC})$, germination percentage $(\% \mathrm{G})$, percentage of

Table 1. Summary of the analysis of variance with the square values of the moisture content (MC), electrical conductivity (EC), germination

\begin{tabular}{|c|c|c|c|c|c|c|c|c|c|c|c|}
\hline FV & GL & $\begin{array}{c}\text { MC } \\
\text { (\% b.u.) }\end{array}$ & $\begin{array}{c}\text { EC } \\
\left(\mu \mathrm{Scm}^{-1} \mathrm{~g}^{-1}\right)\end{array}$ & $\% \mathrm{G}$ & $\begin{array}{c}\text { Fermented } \\
(\%)\end{array}$ & $\begin{array}{c}\text { Burnt } \\
(\%)\end{array}$ & ${ }^{\circ} \mathrm{h}$ & $\mathrm{C}^{*}$ & $\mathrm{~L}^{*}$ & $a^{*}$ & $b^{*}$ \\
\hline Time & 6 & $0.04^{\mathrm{NS}}$ & $4.43^{\mathrm{NS}}$ & $32.65^{\mathrm{NS}}$ & $10.64^{* *}$ & $0.18^{\mathrm{NS}}$ & $0.001^{\star}$ & $6.40^{\mathrm{NS}}$ & $6.93^{\mathrm{NS}}$ & $4.10^{\mathrm{NS}}$ & $7.81^{\mathrm{NS}}$ \\
\hline Residue & 14 & 0.09 & 3.57 & 16.63 & 2.10 & 0.27 & 0.0004 & 7.20 & 4.62 & 4.89 & 10.71 \\
\hline CV (\%) & & 3.52 & 8.65 & 8.16 & 12.50 & 100.24 & 1.86 & 6.00 & 3.70 & 12.06 & 8.12 \\
\hline $\begin{array}{c}\text { Media } \\
\text { General }\end{array}$ & & 8.70 & 21.84 & 49.98 & 11.60 & 0.52 & 1.15 & 44.69 & 58.14 & 18.34 & 40.32 \\
\hline
\end{tabular}
percentage $(\% \mathrm{G})$, hue angle $\left({ }^{\circ} \mathrm{h}\right)$, chroma $\left(\mathrm{C}^{\star}\right), \mathrm{L}^{\star}, \mathrm{a}^{\star}$ and $\mathrm{b}^{\star}$ and the times of ozonation at a $5 \%$ significance. 
fermented and burnt grains, colour parameters angle hue $\left(\mathrm{h}^{\circ}\right)$ and chroma $\left(C^{*}\right), L^{*}, a^{*}$ and $b^{*}$ of maize grains in different periods of ozonation.

Note that there was no effect of ozonation time on moisture content, electrical conductivity and germination percentage. Similar to the ozonation time for fermented grains, the overall average was only lower among ozonization times for the burnt grains, indicating less damage occurred to the grain.

In previous electrical conductivity studies, Nascimento et al. (2008) found that applying ozone in coffee pulp treatment did not interfere with electrical conductivity.

The results obtained by Rozado (2013) indicate that ozone did not interfere with the electrical conductivity and germination of maize and also found that the moisture content increased in grain infested by insects, ozonated and stored in metallic silos.

According to Silva (2011), ozone gas did not affect the classification of wheat grains, which is contrary to the results observed in this study (Table 1).

It is also noted (Table 1) that the ozonation time only affected the hue angle. The results are compared for the hue angle, according to Alencar (2009), verifying that there the effect of ozone was also obtained in peanut kernels.

Table 2 shows the average percentage of fermented grain, according to the different periods of ozonation.

The grains without ozonation $(0 \mathrm{~h})$ differed from the other grains indicating that there was a higher amount of fermented grains. With ozonation, there was a decrease in the fermented grain values, which occurs due to the oxidative power of ozone gas (Rozado, 2005).

Table 2. Average percentage of fermented grain for the different periods of exposure to ozone.

\begin{tabular}{cc}
\hline Time $\mathrm{O}_{3}(\mathrm{~h})$ & Fermented (\%) \\
\hline 0 & $15.53 \mathrm{~b}$ \\
4 & $11.90 \mathrm{a}$ \\
8 & $11.63 \mathrm{a}$ \\
12 & $11.40 \mathrm{a}$ \\
16 & $10.50 \mathrm{a}$ \\
20 & $10.30 \mathrm{a}$ \\
24 & $9.93 \mathrm{a}$ \\
\hline
\end{tabular}

The means followed by the same letter in the column do not differ by the Scott-Knott test at $5 \%$ significance.
Table 3 presents the summary of the analysis of variance for the carbohydrates, ash, crude protein, crude fibre, lipids and moisture content of corn grain ground for the proximate analysis and subjected to different times of ozonation.

There was effect on the ozonation time for the ash and lipid variables. Regarding the lipids, the results show the same behaviour observed by Benevenuto (2013), which evaluated a mixture of ozonated ground corn and soybean meal and found that there was no effect of the gas with a reduction in lipid content.

Note that the effect of ozone on ash for the variable times of 0,4 and $16 \mathrm{~h}$ is higher than that for $8,12,20$ and $24 \mathrm{~h}$. For the lipid content, 8, 12, 16 and $24 \mathrm{~h}$ was a higher effect than the other times. Table 4 shows the average values for the ash levels and lipids by ozonation time.

According to Alencar (2009), the ozonation times of $0,24,48,72$ and $96 \mathrm{~h}$ was no effect on the lipid content of peanut kernels. Pereira et al. (2016) found that the lipid content in maize grain is oxidized by ozone.

Exposure time did not be an effect on PAHs present in maize grain. According to Letzel et al. (1999), ozone degradation was no effect on benzo degradation products (a) pyrene ozonated using the B [def] C-lactone, contradicting the results of this study. The mean PAH values for benzo (a) anthracene, chrysene and 5 -metilcriseno were $0.09,0.32$ and 0.28 , respectively, indicating that the concentrations were low in the ozonated maize samples.

Tables 5 and 6 presents the summary of the analysis of variance and values for the PAHs, respectively, detected in corn grains (benzo (a) anthracene, chrysene, 5-metilcriseno, benzo (b) fluoranthene, benzo (k) fluoranthene and benzo (a) pyrene) according to different ozone exposure times. The other PAHs (BJF, DalP, Daha, ICDP, DAEP, EOAD and DAHP) were not detected in the samples (LOD of $0.12 \mu \mathrm{g} \mathrm{kg}^{-1}$, except for ICDP and BJF, whose LOD is $1.2 \mu \mathrm{g} \mathrm{kg}^{-1}$ ).

For infant foods made from cereals, European legislation mandates a limit of $1.0 \mu \mathrm{g} \mathrm{kg}^{-1}$ for benzo (a) pyrene and $1.0 \mu \mathrm{g} \mathrm{kg}^{-1}$ for pAH4 (The Commission of the European Communities, 2011). In Brazil, the legislation only sets limits for $\mathrm{BaP}$ in the following categories: drinking water, smoke aroma and olive pomace oil (Brasil, 2003, 2004, 2007).

Haapea \& Tuhkanen (2006) studied the effect of ozone on HPAs present in the soil, and the removal of these compounds using ozone gas occurred $90 \%$ of the time, which corroborates our results (Table 6). Alencar (2009), studying ozonized peanut kernels, described a possible reason for the inefficiency Ozone

Table 3. Summary of the analysis of variance with the mean square values of the variables carbohydrate, ash, crude protein, crude fiber, lipids and moisture content as a function of ozonation times.

\begin{tabular}{cccccccc}
\hline FV & GL & Carbohydrate (\%) & Ash (\%) & CrudeProtein (\%) & Crude Fibre(\%) & $\begin{array}{c}\text { Lipids (\%) } \\
\text { Moisture content } \\
(\% \text { b.u.) }\end{array}$ \\
\hline Time & 6 & $1.07^{\mathrm{NS}}$ & $1.01^{* *}$ & $0.09^{\mathrm{NS}}$ & $0.14^{\mathrm{NS}}$ & $1.17^{* *}$ & $0.25^{\mathrm{NS}}$ \\
Residue & 14 & 1.09 & 0.13 & 0.21 & 0.26 & 0.09 & 0.12 \\
CV (\%) & & 1.47 & 15.22 & 5.03 & 15.57 & 5.87 & 3.93 \\
Média General & & 71.40 & 2.35 & 9.15 & 3.30 & 5.05 \\
\hline
\end{tabular}

** Significant at $1 \%$ by F test; NS: not significant. 
Table 4. Average of the ash and lipid variables by ozonation time.

\begin{tabular}{ccc}
\hline Time $\mathbf{O}_{3}(\mathbf{h})$ & Ash (\%) & Lipids (\%) \\
\hline 0 & $3.06 \mathrm{~b}$ & $4.67 \mathrm{a}$ \\
4 & $2.83 \mathrm{~b}$ & $4.32 \mathrm{a}$ \\
8 & $1.68 \mathrm{a}$ & $5.72 \mathrm{~b}$ \\
12 & $1.65 \mathrm{a}$ & $5.73 \mathrm{~b}$ \\
16 & $2.95 \mathrm{~b}$ & $5.11 \mathrm{~b}$ \\
20 & $2.12 \mathrm{a}$ & $4.30 \mathrm{a}$ \\
24 & $2.02 \mathrm{a}$ & $5.47 \mathrm{~b}$ \\
\hline
\end{tabular}

The means followed by the same letter in the column do not differ by the Scott-Knott test at $5 \%$ significance.

Table 5. Summary of the analysis of variance with the mean square values of the PAHs benzo (a) anthracene (BaA), chrysene (Chr), 5-metilcriseno (5MChr), benzo (b) fluoranthene (BbF), benzo (k) fluoranthene (BKF) and benzo (a) pyrene (BaP) by ozonation times.

\begin{tabular}{cccccccc}
\hline FV & GL & $\mathrm{BaA}\left(\mu \mathrm{g} \mathrm{L}^{-1}\right)$ & $\mathrm{Chr}\left(\mu \mathrm{g} \mathrm{L}^{-1}\right)$ & $5 \mathrm{MChr}\left(\mu \mathrm{g} \mathrm{L}^{-1}\right)$ & $\mathrm{BbF}\left(\mu \mathrm{g} \mathrm{L}^{-1}\right)$ & $\mathrm{BkF}\left(\mu \mathrm{g} \mathrm{L}^{-1}\right)$ & $\mathrm{BaP}\left(\mu \mathrm{g} \mathrm{L}^{-1}\right)$ \\
\hline Time & 6 & $0.002^{\mathrm{NS}}$ & $0.05^{\mathrm{NS}}$ & $0.01^{\mathrm{NS}}$ & $0.02^{\mathrm{NS}}$ & $0.001^{\mathrm{NS}}$ & $0.05^{\mathrm{NS}}$ \\
Residue & 14 & 0.002 & 0.02 & 0.02 & 0.05 & 0.001 & 30.40 \\
$\mathrm{CV}(\%)$ & & 147.14 & 99.84 & 52.78 & 31.16 & 0.02 & 0.01 \\
Media & & 0.03 & 0.14 & 0.24 & 0.26 & 0.43 \\
General & & & & & & \\
\hline
\end{tabular}

Table 6. Values of PAHs ( $\mu \mathrm{g} \mathrm{kg}^{-1}$ ) detected in corn grains (benzo (a) anthracene, chrysene, 5-metilcriseno, benzo (b) fluoranthene, benzo (k) fluoranthene and benzo (a) pyrene) according to different ozone exposure times.

\begin{tabular}{|c|c|c|c|c|c|c|c|c|}
\hline \multirow{2}{*}{ PAHs } & \multicolumn{8}{|c|}{ Ozone exposure times (h) } \\
\hline & 0 & 4 & 8 & 12 & 16 & 20 & 24 & Average \\
\hline Chrysene & 0.08 & 0.03 & 0.33 & 0.23 & 0.24 & 0.00 & 0.00 & 0.13 \\
\hline benzo (b) fluoranthene & 0.19 & 0.20 & 0.26 & 0.32 & 0.32 & 0.18 & 0.39 & 0.27 \\
\hline benzo (k) fluoranthene & 0.10 & 0.15 & 0.10 & 0.14 & 0.10 & 0.08 & 0.11 & 0.11 \\
\hline benzo (a) pyrene & 0.48 & 0.20 & 0.40 & 0.43 & 0.40 & 0.31 & 0.67 & 0.41 \\
\hline
\end{tabular}

gas may be present in the moisture content of the grains, since a lower moisture content in the produced gas decreased efficiency.

\section{Conclusions}

Convective drying in a direct fire furnace promotes the contamination of maize grains by PAHs.

The ozonation times influence on the quality of maize grain as lipids, ash and germination percentage.

The ozonation times used did not promote the degradation of the PAHs present in maize grain.

\section{Acknowledgements}

The Federal Institute Goiano - Campus Rio Verde; CNPq, CAPES, FINEP for financial aid; the CARAMURU; After the Lab for the harvest vegetable products; and the Institute of Food Technology.

\section{References}

Alencar, E. R. (2009). Processo de ozonização de amendoim (Arachis hypogaea l.): cinética de decomposição, efeito fungicida e detoxificante de aflatoxinas e aspectos qualitativos (Tese de doutorado). Universidade Federal de Viçosa, Viçosa.
Alencar, E. R., Faroni, L. R. D., Soares, N. F. F., Carvalho, M. S. C., \& Pereira, K. F. (2010). Effect of the ozonization process on the quality of peanuts and crude oil. Revista Brasileira de Engenharia Agrícola e Ambiental, 15(2), 154-160. http://dx.doi.org/10.1590/ S1415-43662011000200009.

American Society of Agricultural Engineers - ASAE. (2003). ASAE EP4962: agricultural machinery management. In American Society of Agricultural Engineers - ASAE. ASAE Standards (pp. 366-372). St. Joseph: ASAE.

Benevenuto, A. A. Jr., (2013). Características físico-químicas e microbiológicas da mistura milho moído e farelo de soja ozonizada na alimentação de frangos de corte (Tese de doutorado). Universidade Federal de Viçosa, Viçosa.

Bermúdez-Aguirre, D., \& Barbosa-Cánovas, G. V. (2013). Desinfection of selected vegetables under nonthermal treatments: Chlorine, acid citric, ultravioleta light na ozone. Food Control, 29(1), 82-90. http:// dx.doi.org/10.1016/j.foodcont.2012.05.073.

Brasil, Agência Nacional de Vigilância Sanitária - ANVISA. (2003, October 6). Exigir como procedimento de importação para "aceite de orujo de oliva" ou óleo de bagaço e ou caroço de oliva, sem prejuízo da documentação exigida para este fim, a apresentação do laudo de análise do produto quanto à presença de hidrocarbonetos policíclicos aromáticos, especificamente o alfa-benzopireno, com identificação do lote e ou data de produção ou fabricação (Resolução RDC n²81). Diário Oficial [da] República Federativa do Brasil. 
Brasil, Ministério da Saúde. Secretaria de Vigilânica em Saúde. CoordenaçãoGeral de Vigilância em Saúde Ambienta. (2004, March 25). Portaria MS no 518, de 25 de março de 2004. Estabelece os procedimentos e responsabilidades relativos ao controle e vigilância da qualidade da água para consumo humano e seu padrão de potabilidade, e dá outras providências. Diário Oficial [da] República Federativa do Brasil.

Brasil, Ministério da Saúde. Agência Nacional de Vigilância Sanitária ANVISA. (2007, January 17). Resolução RDC n² 2, de 17 janeiro de 2007. Aprova o "Regulamento Técnico sobre Aditivos Aromatizantes". Diário Oficial [da] República Federativa do Brasil.

Brasil, Ministério da Agricultura, Pecuária e Abastecimento. (2010, January 07). Portaria $\mathrm{n}^{\circ} 4$, de 06 janeiro de 2010. Submete à consulta pública, por um prazo de 180 (cento e oitenta) dias, o Projeto de Instrução Normativa que aprova o Regulamento Técnico do Milho. Diário Oficial [da] República Federativa do Brasil.

Camargo, M. C. R., Tfouni, S. A. V., Vitorino, S. H. P., Menegário, T. F., \& Toledo, M. C. F. (2007). Determinação de hidrocarbonetos policíclicos aromáticos (HPAs) em guaraná em pó (Paullinia cupana). Food Science and Technology, 26(1), 230-234. http://dx.doi. org/10.1590/S0101-20612006000100036.

Camilo, J. S., Barbieri, V. H. B., Rangel, R. M., Bonnas, D. S., Luz, J. M. Q., \& Oliveira, R. C. (2015). Aceitação sensorial de híbridos de milho doce e híbridos de milho verde em intervalos de colheita. Revista Ceres, 62(1), 1-8. http://dx.doi.org/10.1590/0034-737X201562010001.

Cantalejo, M. J., Zouaghi, F., \& Pérez-Arnedo, I. (2016). Combined effects of ozone and freeze-drying on the shelf - life of Broiler chicken meat. Food Science and Technology, 68, 400-407.

Clesceri, L. S., \& Greenberg, A. E. \& Eaton, A. D. (2000). Standard methods for the examination of water and wastewater (1220 p.) Denver: American Water Works Association.

Drabova, L., Tomaniova, M., Kalachova, K., Kocourek, V., Hajslova, J., \& Pulkrabova, J. (2013). Application of solid phase extraction and two-dimensional gas chromatography coupled with timeof-fligt mass spectrometry for fast analysis of polycyclic aromatic hydrocarbons in vegetable oils. Food Control, 33(2), 489-497. http:// dx.doi.org/10.1016/j.foodcont.2013.03.018.

Haapea, P., \& Tuhkanen, T. (2006). Integrated treatment of PAH contaminated soil by soil washing, ozonization and biological treatment. Journal of Hazardous Materials, 136(2), 244-250. http:// dx.doi.org/10.1016/j.jhazmat.2005.12.033. PMid:16455197.

International Agency for Research on Cancer - IARC. (2010). Monographs on the evaluation of carcinogenic risk to humans. In A review of human carcinogens: chemical agents and related occupations (Vol. 100F). Lyon: IARC.

Klautau, J. V. P. (2008). Análise experimental de uma fornalha a lenha de fluxo cocorrente para secagem de grãos (Dissertação de mestrado). Universidade Federal do Paraná, Curitiba.

Laureano, J., Giacosa, S., Rio Segade, S., Torchio, F., Cravero, F., Gerbi, V., Englezos, V., Carboni, C., Cocolin, L., Rantsiou, K., Faroni, L. R. D., \& Rolle, L. (2016). Effects of continuous exposure to ozone gas and electrolyzed water on the skin hardness of table and wine grape varieties. Journal of Texture Studies, 47(1), 40-48. http://dx.doi. org/10.1111/jtxs.12158.

Letzel, T., Rosenberg, E., Wissiack, R., Grasserbauer, M., \& Niessner, R. (1999). Separation and identification of polar degradation products of benzo[a]pyrene with ozone by atmospheric pressure chemical ionization-mass spectrometry after optimized column chromatographic clean-up. Journal of Chromatography. A, 855(2), 501-514. http://dx.doi.org/10.1016/S0021-9673(99)00716-5. PMid:10519088.
Maguire, J. D. (1962). Speed of germination-aid in selection and evaluation for seedlig emergence and vigor. Crop Science, 2(1), 176-177. http:// dx.doi.org/10.2135/cropsci1962.0011183X000200020033x.

Nascimento, L. C., Lima, L. C. O., Picolli, R. H., Fiorini, J. E., Duarte, S. M. S., Silva, J. M. S. F., Oliveira, N. M. S., \& Veiga, S. M. O. M. (2008). Ozônio e ultra-som: processos alternativos para o tratamento do café despolpado. Food Science and Technology, 28(2), 282-294. http://dx.doi.org/10.1590/S0101-20612008000200004.

Ong, M. K., Kazi, F. K., Forney, C. F., \& Ali, A. (2013). Effect of gaseous ozone on papaya anthracnose. Food and Bioprocess Technology, 6(11), 2996-3005. http://dx.doi.org/10.1007/s11947-012-1013-4.

Pereira, A. M., Faroni, L. R. D., Silva Júnior, A. G., Sousa, A. H., \& Paes, J. L. (2008). Viabilidade econômica do gás ozônio como fumigante em grãos de milho armazenados. Engenharia na Agricultura, 16(2), 144-154. http://dx.doi.org/10.13083/1414-3984.v16n02a02.

Pereira, A. M., Faroni, L. R. D., Sousa, A. H., Marco, J. L. P., \& Silva, M. T. C. (2016, Oct. 15-18). Evaluation of oil extracted from corn grains ozonized at different levels of grain mass temperature. In I. Lorini, B. Bacaltchuk, H. Beckel, D. Deckers, E. Sundfeld, J. P. Santos, J. D. Biagi, J. C. Celaro, L. R. D’A. Faroni, L. O. F. Bortolini, M. R. Sartori, M. C. Elias, R. N. C. Guedes, R. G. Fonseca \& V. M. Scussel (Eds.), Proceedings of the 9th International Working Conference on Stored Product Protection (pp. 605-611). Passo Fundo: Brazilian Post-Harvest Association.

Pinto, A. P., Lançanova, J. A. C., Lugão, S. M. B., Roque, A. P., Abrahão, J. J. S., Oliveira, J. S., Leme, M. C. J., \& Mizubuti, I. Y. (2010). Avaliação de doze cultivares de milho (Zea mays L.) para silagem. Semina: Ciências Agrárias, 31(4), 1071-1078. http://dx.doi.org/10.5433/16790359.2010v31n4p1071.

Rocha-Olivieri, C. M., Conti-Silva, A. C., \& Lopes-Filho, J. F. (2012). Physical-chemical and microbiological characteristics of fibrous components obtained from corn wet milling. Revista do Instituto Adolfo Lutz, 71(4), 728-732.

Rojo Camargo, M. C., \& Toledo, M. C. F. (2003). Polycyclic aromatic hydrocarbons in Brazilian vegetables and fruits. Food Control, 14(1), 49-53. http://dx.doi.org/10.1016/S0956-7135(02)00052-X.

Rozado, A. F. (2005). Ozônio como fumigante na proteção de milho armazenado (Dissertação de mestrado). Universidade Federal de Viçosa, Viçosa.

Rozado, A. F. (2013). Distribuição do gás ozônio em milho armazenado em silo metálico usando sistema de aeração (Tese de doutorado). Universidade Federal de Viçosa, Viçosa.

Rozentãle, I., Stumpe-Viksna, I., Zacs, D., Siksna, I., Melngaile, A., \& Bartkevics, V. (2015). Assesment of dietary exposure to polycyclic aromatic hydrocarbons from smoked meat products produced in Latvia. Food Control, 54, 16-22. http://dx.doi.org/10.1016/j. foodcont.2015.01.017.

Silva, D. J., \& Queiroz, A. C. (2006). Análise de alimentos: métodos químicos e biológicos (3rd ed.). Viçosa: Universidade Federal de Viçosa.

Silva, T. A. (2011). Processo de ozonização dos grãos de trigo: cinética de reação e efeito na qualidade destes e da farinha (Dissertação de mestrado). Universidade Federal de Viçosa, Viçosa.

Speer, K., Steeg, E., Horstmann, P., Kühn, T., \& Montag, A. (1990). Determination and distribution of polycyclic aromatic hydrocarbons in native vegetable oils, smoked fish products, mussels and oysters, and bream from the river Elbe. Journal of High Resolution Chromatography, 13(2), 104-111. http://dx.doi.org/10.1002/jhrc.1240130206.

Tfouni, S. A. V., Padovani, G. R., Reis, R. M., Furlani, R. P. Z., \& Camargo, M. C. R. (2014). Incidence of polycyclic aromatic hydrocarbons 
in vegetable oil blends. Food Control, 46, 539-543. http://dx.doi. org/10.1016/j.foodcont.2014.06.028.

The Commission of the European Communities - CEC. (2011, August 19). Commission Regulation (EC) No 835/2011 of 19 August 2011 amending Regulation (EC) No 1881/2006 as regards maximum levels for polycyclic aromatic hydrocarbons in foodstuffs. Official Journal of European Union.

Venegas, J. G., Harris, R. S., \& Simon, B. A. (1998). A comprehensive equation for the pulmonary pressure. Journal of Applied Physiology, 84(1), 389-395. http://dx.doi.org/10.1152/jappl.1998.84.1.389. PMid:9451661.

Vieira, R. D., \& Krzyzanowski, F. C. (1999). Teste de condutividade elétrica. In F. C. Krzyzanowski, R. D. VIEIRA \& J. B. França No, (Eds.), Vigor de sementes: conceitos e testes (cap. 4, pp. 1-26). Londrina: ABRATES.

Wang, W., Simonich, S., Giri, B., Chang, Y., Zhang, Y., Jia, Y., Tao, S., Wang, R., Wang, B., Li, W., Cao, J., \& Lu, X. (2011). Atmosphereic concentrations and air-soil gas exchangeof polycyclic aromatic hydrocarbons (PAHs) in remote, rural village and urbans áreas of Beijing - Tianjin region, North China. The Science of the Total Environment, 409(15), 2942-2950. http://dx.doi.org/10.1016/j. scitotenv.2011.04.021. PMid:21669328.

White, S. D., Murphy, P. T., Bern, C. J., \& van Leeuwen, J. H. (2010). Controlling deterioration of high-moisture maize with ozone treatment. Journal of Stored Products Research, 46(1), 7-12. http:// dx.doi.org/10.1016/j.jspr.2009.07.002.

World Health Organization - WHO, Food and Agriculture Organization of the United Nations. (2005). Summary and conclusions of the sixty fourth meeting of the Joint FAO/WHO Expert Committee on Food Additives. Roma: WHO.

Xu, X., Hu, H., Kearney, G. D., Kan, H., \& Sheps, D. S. (2013). Studying the effects of polycyclic aromatic hydroarbons on perifheral arterial disease in the United States. The Science of the Total Environment, 461-462, 341-347. http://dx.doi.org/10.1016/j.scitotenv.2013.04.089. PMid:23747551. 